\title{
Kuyucaklı Yusuf Romanının Kadın Kahramanlarını Toplumsal Cinsiyet Bağlamında Psikososyal Yönleriyle Ele Almak
}

\author{
AZIZ ŞEKER* \\ shuaziz@gmail.com \\ ORCID ID: 0000-0001-5634-0221
}

Öz: Sabahattin Alinin Kuyucaklı Yusuf'u, yazıldiğı sosyal-tarihsel dönemin toplumsal yapısının birçok özelliğini başarıyla işlemiş bir romandır. Sosyal içerikli bu roman, 1900'lü yılların başında Ege'de farklı kültürlerden insanların bir arada yaşadıkları bir kasabada; ailesi eşkıyalar tarafindan katledilen kimsesiz Yusuf'un evlatlık alındığ ailedeki durumunu, kendisiyle ve toplumla ilişkisinin yan sıraromanın geçtiği toplumsal gerçek içinde farklı toplumsal tabakalardan insanlarm, gruplarm ekonomik, sosyal kültürel yönlerini de konu ediniyor. Romanda, toplumsal cinsiyet hiyerarşisini inşa eden erkeklerin egemen olduğu ataerkil bir toplumda, kadınların sosyal konumların yakından görüyoruz. Bu çalışmada, toplumsal cinsiyet kurulumunun kadınlarm aleyhine olduğu bir toplumsal sistemi romanda geçen olaylar ekseninde tartışırken, romanın kadın kahramanlarının (Muazzez, Şahinde, Çineli Kübra) yaşamların da psikososyal açıdan ele alacağız. Roman kadın kahramanlarının, toplumsal gerçeği yansitan toplumsal cinsiyet olgusundan yola çıkılarak analiz edilmesinin, cinsiyetçi dilin romandaki görünürlüğünü de eleştirel olarak değerlendirmemize katkı sağlayacağ düşünülmektedir.

Anahtar kelimeler: Roman, Toplumsal cinsiyet, Kadın, Toplumsal cinsiyet ayrımcılığı.

\section{Giriş}

Kuyucaklı Yusuf, 1900'lü (1903-1915) yılların başında Aydın Nazilli'de başlayıp Balıkesir'in Edremit kasabasında Birinci Dünya Savaşı içinde sona eren sosyal konulu bir romandır. ${ }^{1}$ Sabahattin Ali, Kuyucaklı Yusufu Kadro Dergisi'nin ilk sayısının ve Yaban'ın yayımlandığg 1932 yılında yazmaya başlamış, fakat eser ilk baskısını gecikmeli olarak 1937'de yapabilmiştir. Kuyucaklı Yusuf, Kemalist rejimin sınırlarını soldan zorlayarak toplumcu eleştirinin ögelerini taşıması bakımından da öncü romanlar arasında yer almaktadır. ${ }^{2}$ Roman, "1903 senesi sonbaharında ve yağmurlu bir gecede Aydın’n Nazilli kazasına yakın Kuyucak köyünü eşkıyalar bastılar ve bir karı

* Dr., Sosyal Hizmet Uzmanı, Amasya Üniversitesi.

1 Fethi Naci, 100 Soruda Türkiye'de Roman ve Toplumsal Değişme, İstanbul: Gerçek Yayınevi, 1990, s.319.

2 Taner Timur, Osmanlı-Türk Romanında Tarih, Toplum ve Kültür, İstanbul: İmge Kitabevi, 2002, s.94. 
kocayı öldürdüler’3 cümlesiyle başlar. Romanın erkek kahramanlarından Yusuf'un gözlerinin önünde, eşkıyalar tarafından annesi ile babası öldürülmüştür. Olay yerine gelenler arasında yer alan kaymakamın sorduğu soruları, olayda bir parmağı kopan Yusuf serinkanlı bir şekilde cevaplar. Oracıkta Yusuf, büyütecek kimsesi geride kalmadığı için kaymakam tarafından evlatlık edinilir. Kaymakamın ailesi ile Edremit’e yerleştiğinde Yusuf, kendisine göre insanların yalan söylemediği bir köyden, insanların kolaylıkla neden yalan söylediklerini düşündügü bir kasabada yaşamaya başlar. Yusuf'un travmatik geçmişi, yaşadığı toplumsal çevrede bunaltı içinde büyüyen bir kişiliğe sahip olmasını beraberinde getirecektir. Yusuf'un davranışlarındaki tereddütler, çaresiz kalışları, bazı olaylar karşısında bireysel irade geliştirememiş olması, kararsız bir kişiliği olduğu yönünde bir izlenim vermektedir. Ayrıca yetişkinliğe adım attığı kasabanın, feodal ve ataerkil bir sosyal yapıda olması dakişiliğinin oluşmasında etkili olacaktır.

Yazar, romanın geçtiği yerleşim yeriyle ilgili bir sosyal çerçeve çizerken, romanın kahramanlarının işlendiği sosyal dünyanın gerçekliğini estetize ederek, Müslümanların, Rumların ve çeşitli kültürlerden insanların yaşamlarını roman sayfalarına taşır. ${ }^{4} \mathrm{Bu}$ geniş sosyal-kültürel yapı içinde büyüyen Yusuf, üvey kardeşi Muazzez’le birçok olaydan sonra evlenecektir. Çalışma ilerledikçe göreceğiz ki, on beş yaşındaki Muazzez kasabalılarla girmiş olduğu ilişkilerde hep merkezi bir yerde olmuştur. Kasabanın ileri gelenlerinin onu kullanmaya dönük ilgisi roman boyunca sürer.

Romanda, Edremit’te köylü ve kasabalı insanların yaşam mücadeleleri, bazı zengin eşraf ile yereldeki devlet bürokrasisinin araçlarının yozlaşmış değerler etrafında bir araya gelmeleri, çeşitli olaylar ekseninde işlenir. Kasabanın ileri gelenlerinden zengin fabrikatör Hilmi Bey ve ahlaki açıdan sorunlu oğlu Şakir’i koruyan ve bu uğurda her türlü kötülüğü yapabilecek Hacı Etem’in içinde yer aldığı insan ilişkilerinin karmaşık yüzünün sergilenmesi, romana psikolojik bir derinlik kazandırır. Bu yönüyle Kuyucakl Yusuf, toplumsal yozlaşmanın, kokuşmanın yaygın olduğu, insan haysiyetinin zedelendiği kurulu düzene karşı bir roman olarak da kabul edilmektedir. ${ }^{5}$ Romanda kamu çalışanlarının güvensiz tutumlarının varlığı halkın adalet arayışını engellerken, bunun arkasındaki güç odaklarının, toplumda nasıl bir sosyal kontrol aracı olabileceğine tanıklık ederiz. Roman konusunun bu temelde kurgulanmasında, yazarın toplumcu kimliğe sahip olmasının işlevsel olduğunu söylemek mümkündür. Toplumcu gerçekçi anlayışa dayanarak kaleme alınan romanların, toplumsal gerçeği yansıttıkları düşünüldüğünde, yazarın kendi toplumcu düşünce yapısının bir gereği olarak, toplumsal yapıyla ilgili birçok sorunu ve çelişkiyi roman malzemesi biçiminde kullanması beklenen bir davranıştır. ${ }^{6}$ Ancak şu ayrıntıyı anımsatmakta fayda görmekteyiz: Her şeyden önce gerçeklik temeli olsa dahi, roman bir kurgudur. Roman kahramanları, yazarın gözlemlerinin ve hayal gücünün ürünleri olarak kur-

3 Sabahattin Ali, Kuyucakl Yusuf, İstanbul: Cem Yayınevi, 1991, s.21.

4 Ömer Türkeş, “Toplum ve Kimlik Kurma Kılavuzu Olarak Roman", Modern Türkiye’de Siyasi Düşünce, Dönemler ve Zihniyetler, ed., Tanıl Bora, Murat Gültekingil, İstanbul: İletişim Yayınları, 2009, s.844.

5 Sevim Kantarcıoğlu, Yakınçağ Tarihimizde Roman, 1908-1960, İstanbul: Paradigma Yayınları, 2008, s.321.

6 Erem Sarıkoca, Tarihi Güncellemek- Edebiyat Sosyolojisi Açısından Roman, Erzurum: Fenomen Yayıncilık, 2016, s.9. 
maca dünyada karşımıza çıkarlar. ${ }^{7}$ Başka bir ifadeyle roman kahramanları, varoluş kavgası verseler de canlı bir varlığın taklidinden ziyade kurmaca birer varlıktırlar. ${ }^{8}$

Kasabanın zengin azınlığı, kasaba toplumunun üzerinde korku oluşturulmasında ve haksız kazanç edinilmesinde hak ve söz sahibidir. Yerel bürokrasinin elemanlarının bu konuda sessiz kaldığı, hatta zengin azınlığın üyeleriyle zaman geçirdiği gözlenmektedir. Örneğin bir düğünde Muazzez’e âşık olan Ali’nin, Şakir tarafından öldürülmesi sonrasında, Hacı Etem Bey’in, şahitlerin fikirlerini değiştirmesi bir yana karakol komutanını bile satın alması sonucunda, Şakir'in serbest bırakılması olayı bunu destekler. Romanda, kasabanın toplumsal ve somut nesnel koşulları, kahramanların dış çevresini bu tür olaylar etrafında yapılandırır. Keza Yusuf'un, üvey babasının ölümü sonrasında kasabaya yeni gelen Kaymakam İzzet Bey’in, kasabanın eşraflarının oluşturduğu sosyal ilişkilerin içinde yerini alması, bu gruplara karakol komutanın dâhil olmasını izleyen halk, eşrafın kamu idarecileri üzerindeki baskısını bildiği için en küçük bir adalet arayışına girip başka sorunlarla karşılaşmak istememektedir. Bu nedenle yoksulluk ve diğer sorunlar sarmalında eşrafın yönlendirdiği kasaba insanlarının, kendi sorunlarına çözüm arayışları sonuçsuz kalmaktadır. Romanda, toplumsal tabakasına göre sınırlandırılmış, gelirleri oranında kamusal alanda görünür olmaya çalışan halk pek bir varlık gösterememektedir. Bireysel hak arayışları bile kasabada yaşanan olayların adaletsizliğini besleyenlerin, psikolojik duvarına gelip çarparak bir anlam ifade etmemektedir. Roman kompozisyonundan çıkaracağımız şey, zor değişen adaletsizliklerle kurulu bir sosyal yapıda, insanın çaresizliğinin somut olarak işlenmiş olmasıdır. Yazarın odaklandığ bir sorgulamayı beraberinde getirmektedir. Bu noktada romanın kadın kahramanları arasında Muazzez’in sonu ölüme varacak kısacık yaşamının anlamını çözümlemek, romanın yazıldığı dönemin toplumsal cinsiyet ilişkilerini görmek bakımından aydınlatıcı olacaktır. Yusuf'un, evin ekonomik sorunlarını çözemeyişi, Muazzez'in, annesinin yönlendirmesinde kalarak kasaba eşrafının davetlerine gidip, erkeklerin bir tür oyuncağı olması sonrasında, erkeklerin kavgasından çıkan bir kurşunla ölümü, elbette önümüze analiz edilmesi gereken eleştirel bir psikolojik ve sosyal alan açmaktadır.

Kuyucaklı Yusuf, kadınların toplum içindeki sosyal durumlarını, iletişim örüntülerini ve cinsiyetçi koşullarda var oluş tarzlarını görmemiz açısından önemli veriler içerir. Örneğin tecavüz mağduru Kübra’nın annesiyle bir başına kalışı, Yusuf'un gözetimiyle evlerinde hizmetçilik edişleri, kaymakamın ve Yusuf'un bilmesine rağmen tecavüz olayıyla ilgili suç işlemiş eşrafın şikâyet konusu yapılmaması, ataerkil toplumun kadınlar aleyhine son derece aşağılayıcı yanına işaret eder. Açıkçası toplum kurulumunda, toplumsal sinıfların ya da değişik toplumsal kesimlerin düzen açısından işleyişinin toplumsal cinsiyet örüntüleriyle birlikte var olduğunu, hatta iç içe geçtiğini belirtebiliriz. ${ }^{9}$ Kuyucaklı Yusufta idari ve adli kurumlarda yapılan

7 Gülsüm Tarakçı, “İki Roman Örneğinde Milli Roman”, Türk Romanı Özel Sayısı, Hece Aylık Edebiyat Dergisi, 6/65-66-67, (2002), s.486.

8 Milan Kundera, Roman Sanatı, çev., Aysel Bora, İstanbul: Can Sanat Yayınları, 2014, s.41.

9 Serpil, Sancar, Türk Modernleşmesinin Cinsiyeti, Erkekler Devlet, Kadınlar Aile Kurar, İstanbul: İletişim Yayınları, 2014, s.261. 
haksızlıklara, toplum hayatının günlük akışı içinde de rastlanır. Kübra ve annesi ile temsil edilen ve "dillerini” Yusuf’tan başka kimselerin pek anlamadığı veya anlamak istemediği zeytin işçileri, hiçbir sosyal güvenceye sahip değillerdir. Bu insanların iş güçleri yanında bedenleri ve insanlık onurları da firsatçı "kasaba mütegallibesi” tarafından sömürülmekte ve ayaklar altına alınmaktadır. Kübra ve annesini boğaz tokluğuna çalıştıran Hilmi Bey tahifesi, bununla yetinmeyip bir dağ evinde Kübra'nın namusunu kirletmekten çekinmezler. ${ }^{10}$ Denebilir ki, annesiyle yaşayan ve hizmetçilik yaparak geçinen Çine'li Kübra’nın uğradığı cinsel istismar karşısında, adalet arayışları, kasabanın ileri gelenleri tarafından işletilmemiştir. Kasabada kamu otoritesinin başındaki kaymakamın farkında olmasına rağmen, onlara yardım edemeyişi tartışmaya açıktır. Oysa çoğu zaman romanlarda hangi kesim anlatılırsa anlatılsın, ailenin namusunu belirleyen en önemli unsur olarak algılandığı için kadının namusuna/iffetine çok önem verilmiştir. Bir erkek veya aile, kadının namusuna sahip çıktığı oranda yücelir veya toplumda şerefli sayılır. ${ }^{11}$ Öte yandan roman kadın kahramanları toplumdaki halleriyle erkeğe bağımlı, güçsüz ve zayıf sosyal tipler olarak oluşturulmuştur. Bu temsiller, dönemin toplumsal yapısı içinde kadın sorunsalının boyutlarını vermesi bakımından anlamlıdır.

Roman kahramanlarından Kaymakam Salâhattin'in karısı yani evin kadını Şahinde, genel hatlarıyla bakıldığında orta yaş üstü, kendi rahatını düşünen, çıkarcı, güven vermeyen, sevgisiz, ataerkil gelenekleri idame ettirici davranışlarıyla betimlenmektedir. Masum ve saf Muazzez, çelişkilerle dolu Yusuf karşısında sevgisini arayan, hissettiren, erkeği için elinden geleni yapan, kendisi dışındaki kötü koşullara yenilmemek için direnen, ancak bir gece erkek toplumundan çıka gelen kurşundan sonra yol kenarına gömülen bir roman kahramanı olarak hafızamızda yer edinir. Aynı zamanda Muazzez, kadın psikososyal gerçekliğini, ataerkil toplumun inşa ettiği ögelerle değerlendirmemize olanak tanıyan özelliklere sahiptir.

Sabahattin Ali'nin roman kurgusundaki önemli bir başarısı sosyal konulara eğilirken, gerçekçi bir üslûba sahip olmasıdır. Roman kahramanlarının konuşmalarında gerçeğe uygunluk sağlamaktadır. Kahramanları yaş, bölge, sosyal statü ve hatta cinsiyetlerinin belirlediği biçimde, gerçek hayatta olduğu gibi konuşturmaktadır. ${ }^{12}$ Romanın başarısını sağlayan bir başka önemli ögeyse Sabahattin Ali’nin olay kurmakta, birbirleriyle bağlantılı olarak ve roman kişileriyle kasaba gerçeğini ortaya çıkaracak biçimde olayları sürdürmekte, giderek bu olaylar dizisine gergin bir dram havası katmaktaki büyük ustalığıdır. Romanın çok sağlam bir olaylar örgüsü vardır ve her olay belli bir görev yüklenmiştir. ${ }^{13}$ Başka bir deyişle, psikolojik tahlillerde başarı gösteren yazar, kahramanlarının iç dünyasına girerek ve yalnız insanın davranışlarını belirleyen somut koşulları değil, kahramanlarının iç yaşamlarını belirleyen öznel ve bireysel koşulları da yakalamaya çalışmıştır. Bu yüzden Sabahattin Ali, yeni ve

10 Ramazan Korkmaz, “Sabahattin Ali -İnsan ve Eser-”, Doktora Tezi, Firat Üniversitesi Sosyal Bilimler Enstitüsü, 1991, s.255-256.

11 Ramazan Gülendam, Türkiye’de Kadın Olmak, Cumhuriyet Devri Türk Romanında Kadın Kimliği, İstanbul: Kesit Yayınları, 2015, s.704.

12 Gürsel Aytaç, Çağdaş Türk Romanı Üzerine İncelemeler, Ankara: Doğu Batı Yayınları, 2012, s.61.

13 Naci, 100 Soruda Türkiye'de Roman ve Toplumsal Değişme, s.319. 
kendi zamanına göre çok tipik kahramanlar yaratmakla kalmamış, bu kişileri hem bireysel hem de evrensel olarak yaratmaya çalışmıştır. ${ }^{14}$ Bu bağlamda Kuyucaklı Yusuf'u, kişilerinin canlılığıyla, ayrıntıları kullanmadaki ustalığıyla, olay örgüsündeki mükemmellikle, yerel renkleri vermedeki üstün başarısıyla, sosyal gerçeklikle insani gerçekliği tam bir uyum içinde, dengeli olarak yansıtmasıyla önemini ve güncelliğini koruyacak bir roman kimliğiyle değerlendirmek gerekir. ${ }^{15}$

\section{Romanın Kadın Kahramanlarının Psikososyal Gerçekliği}

Romanın daha başlangıcında, kadın kahramanlardan Şahinde'nin, nasıl bir karaktere sahip olduğunu, eve geldiği ilk gün Yusuf'a davranış biçiminden çıkarabilmekteyiz: "Kaymakamın karısı Şahinde Hanım, eve bir 'köylü piçinin' getirilmesinden hiç de memnun olmadı ve bunu çocuğun yanında bağıra bağıra söylemekten çekinmedi." ${ }^{\prime 6}$ Şahinde Hanım'ın biyografisine bakarak kişiliğiyle ilgili bir değerlendirmede bulunabiliriz: "Salâhattin Bey, gençliğini deli geçirdikten, hayatın tadılmadık zevkini bırakmadıktan sonra, birdenbire yorgunlaştığını, artık daha fazla koşacak kuvveti olmadiğını görmüş, beş sene kadar evvel, bu kendisinden tam on beş yaş küçük kızla evlenivermişti." ${ }^{\prime 7}$ Kaymakamın kendisinden on beş yaş küçük karısı Şahinde, ev içinde her zaman baskın tip olmuştur. Otuz yaşında evlenen ve geçmişinde onun tabiriyle tatl günahlar işlemiş, "Salâhattin Bey oldukça güzel olan bu kızı evvelâ kendisi ile bir ayarda bir mahlûk gibi, güzel bir kedi, bir kuzu gibi sevdi. Lâkin derhal anladı ki, bu kızcağız kendisini hiç de küçük, basit görmemekte, bir musavat istemektedir."18 Sivri tırnaklar1 ve sert boynuzlarıyla nitelendirdiği bu kadının, sosyal kişiliği romanda "kapalı büyüyen ve bu şekilde bütün tabii arzu ve ihtiyaçlarını içinde hapsetmeğe mecbur olan genç kız, gayet tabii olarak, sinirli ve mânen bozuk bir mahlûk"19 olarak belirtilir. Şahinde’ye yönelik olumsuz bakış açısından ailesi de payına düşeni alır: “... Onlar işportaya konan bir elma gibi onu süsleyip temizlemişler, parlatmışlar, sonra yağlı bir müşteriye okutmuşlardı. Kız yetiştirmekten de gaye bu değil miydi?" ${ }^{20}$ Böyle bir mantık yürütme tarzı, Salâhattin Bey’e aitti ve geleneksel ataerkil toplumlarda erkeklerin kolaylıkla benimsedikleri yaygın bir düşünce yapısını gösteriyordu. Salâhattin Bey’e göre yaşı küçük bir kızın evli gittiği kocasının yanında yetişmesi için, eşi elinden geleni yapmalıydı. Ona doğru yolu göstermeliydi. Salâhattin Bey’in amaçladığı şey, “...şirret ve tecrübesiz kız mevkiinden alıpbir sabır ve feragat melâikesi mertebesine" ${ }^{\text {"21 }}$ ulaşmasını sağlamak olarak aktarılır. Cinsiyetçi toplumsal kabullerin her türlü tartışmayı içinde büyüttüğü hiç de demokratik olmayan bir mahrem alanda, yumuşak başlı Salâhattin Bey ne kadar belirleyici olabilirdi. Kadın üzerinde baskın olamayacağını zamanla anlayacaktır. Bu durum Yusuf'un da ilgilendiği bir konudur. Üvey annesinin davranışlarına dair Yusuf'un cinsiyetçi bir bakış açısına sahip olduğunu şu cümlelerden

\footnotetext{
14 Leyla Alkayeva, "Sabahattin Ali’nin Romanlarında Hümanizm”, Sovyet Türkologlarının Türk Edebiyatı İncelemeleri, çev., Tatyana Moran ve Yurdanur Salman, İstanbul: Cem Yayınevi, 1980, s.82.

15 Naci, 100 Soruda Türkiye’de Roman ve Toplumsal Değişme, s.325.

16 Ali, Kuyucaklı Yusuf, s.27.

17 Ali, Kuyucaklı Yusuf, s.27.

18 Ali, Kuyucaklı Yusuf, s.28-29.

19 Ali, Kuyucaklı Yusuf, s.29.

20 Ali, Kuyucaklı Yusuf, s.29.

21 Ali, Kuyucaklı Yusuf, s. 30.
} 
hareketle çıkarmak mümkündür: "Yusuf bir kadının çenesini bu kadar açabilmesine hayret ediyor, bunlara tahammül eden kaymakama biraz da merhametle bakiyordu. Kendisine karşı yapılan muamelelere aldırış ettiği yoktu. Bir evde sözü geçecek, hükmü yürüyecek yegâne adam o evin erkeği olduğuna ve bu erkek de kendisini istediğine göre, Şahinde Hanımin sözlerinin bir kıymeti olamazdı.”22 Yusuf'un gözünde üvey babanın "aczi", onun karısını yönetmekteki başarısızlığındadır ve bu zayıflık, Salahattin Bey'in otoritesinin kamu alanındaki tüm yansımasını da etkilemektedir. Yazar, onun yaptığı evliliği taşra şehirlerinin gelenek ve göreneklerine karşı şiddetli ve etkili bir polemikle anlatır. Yusuf, ne üvey annesi olan bu kadına tahammül edebilmekte ne de onun şiddetine çaresizce katlanan üvey babasının utanç verici durumunu kabul edebilmektedir. ${ }^{23}$ Yusuf, ailede hükmü yürüyecek tek adam olarak babayı kabul eden bir anlayışı göz ardı etmediğini her defasında belirtir. O günkü ataerkil toplumda, evin erkeğine mutlak itaat ve beklentilerine uyum sağlamak, kadının önündeki kalın duvarı oluşturmaktadır. Yusuf'un bazen kendisine karşı davranışlarından dolayı aşırı tepkiler veren Şahinde için, "karı kısmının sözüne bakılmaz, herhalde senin aklın pek yerinde olmamal!!"24 türünde bir duyguya sahip olması bunu destekler niteliktedir. Aralarında güvene dayalı bir ilişki hiçbir zaman kurulamamıştır. Bu arada Yusuf, kasabada başarısız bir okul deneyimi yaşar. Bu başarısızlığını, Yusuf'un üvey annesi eleş̧irir. Yeri gelecek eşiyle Yusuf için tartıştığında şu cümleleri kullanacaktır: "Sen bilirsin. Fakat bu ahlâksız mahalle piçi hep böyle kopuklukta devam ederse, ben kızımı alı giderim; sen sevgili Yusuf'unla otur ondan sonra." ${ }^{25}$ Üvey baba ikna edici bir şekilde okulda başarı göstermesi için Yusuf'la konuşurken, Yusuf üvey annesinin davranışları karşısında kendisinden okula ilgi göstermesini isteyen üvey babasına söylenmekten geri durmaz: “...şu Şahinde anam sabahacak encek gibi dırlanır durur da bir yolunu bulup onu bile susturamazsin; ne edeyim ben senin okuman??"26

Yusuf, üvey annesi gezmelere gittiğinde Muazzez'le daha çok zaman geçirmeye başlamıştır. Yine aynı evde Rumeli'li ihtiyar bir hizmetçi, çocukların bakımından ve ev içi hizmetlerin yürütülmesinden sorumludur. Kırsalda çalışan kadın olgusuyla ilgili bir parantez açmak gerekirse, hizmetçi kadınların yanında kasabanın zeytinliklerinde çalışan kadınlara romanda kısaca değinilmektedir. Romanda bununla ilgili kısım şöyle geçmektedir: Yusuf babasının zeytinliğine gelen bir kadınla on iki yaşlarındaki kızının çalışmak istediğini görünce onlara yardımcı olmaya çalışır. Şakir Bey'lerin tarlalarında çalışan bu kadınla kızı, kendilerine yaşatılan kötü şeylerden dolayı oradan ayrılmışlardır. Bu anne kız, başlarından geçenleri Yusuf'a yıkmak için önce anlaşmışlardır. Sonra başaramayıp Yusuf'a gerçekleri anlatırlar. Bir gece onların kaldığı yere Yusuf giderken, Hacı Etem de ardı sıra gider. Ancak kadın Yusuf için oynayacakları oyunu dillendirince, Hacı Etem kadını tokatlar, araya giren Yusuf nereden geldiği bilinmez bir bıçakla yaralanır. Sonrasında Yusuf, anne kızı yanlarına hizmetçi alır. Aslında Hilmi Bey, oğlu Şakir Bey ve ayakçıları Hacı Etem bu çocuk yaştaki kıza

22 Ali, Kuyucakl Yusuf, s. 32

23 Ayşe Saraçgil, Bukalemun Erkek, Osmanl İmparatorluğu’nda ve Türkiye Cumhuriyetinde Ataerkil Yapılar ve Modern Edebiyat, çev., Sevim Aktaş ve Öykü Özgün, İstanbul: İletişim Yayınları, 2005, s.319-321.

24 Ali, Kuyucakl Yusuf, s.33.

25 Ali, Kuyucaklı Yusuf, s.35.

26 Ali, Kuyucaklı Yusuf, s.36. 
tecavüzün sorumlusudurlar ve ortaya çıkmaması için ellerinde geleni yapmaktadırlar. Olayı öğrenen kaymakamınsa bir şey yapmaması, Yusuf'un geri durması ve sonrasında evden ayrılan anne ve kızın kimsesizliklerinin, adalet arayışlarında biryere varamayışlarını düşünmeleri, feodal toplumdaki kadın sorunsalını en acı yönüyle sergiler. Öte yandan Hilmi Bey, oğlu Şakire Muazzez'i istemek için uğraş vermektedir. Şakir, Yusuf'a karşı duyduğu nefreti bastırmak ve bir bedel ödetmek uğruna Muazzez’i istemektedir. Bunun nedeni Yusuf'un, bir bayram günü Muazzeze sarkıntılık yapan Şakir'i yumruklamış olmasıdır. Buna rağmen Muazzez'in istenmesi için aileler görüşmektedirler. Olayların boyutunu tam kestiremeyen Muazzez, kendisine takılan bileziklerle gezinirken, Yusuf'un ilk tepkisi üvey kız kardeşine olur, kıza verilen bilezikler karşısında "...Allah versin, senin de canına minnettir. Zengin diye ağzının suyu akıyor, baksana!..”ㄱ diyerek onu aşağılar. Bunun üzerine Muazzez, kollarındaki bilezikleri çıkarıp atar. Geri planda oynadığ 1 kumarı kaybedince kendisine senet imzalatılan kaymakam da sıkıştırılmaktadır. Amaç kaymakamı zor durumda bırakıp, kızını Şakire vermesini sağlamaktır. Yusuf, yüklü senet için, arkadaşı Aliden borç alıp, babasının sorununu çözer. Ondan aldığı 320 lirayı Hacı Etem’e verir. Ama bir karşıllı̆̆ vardır. O da Muazzez! Yusuf, Muazzez'in Ali’yle evlenmesi için uğraşacaktır. Kendisiyle ilgili yürütülen bu alışverişe Muazzez ise tavrını şöyle dile getirir:

"Ağabey beni kaça sattınız?"

Yusuf afalladı ve kızın yüzüne baktt.

Muazzez tekrar etti:

"Daha doğrusu beni kaça sattın?"

"Ne demek istiyorsun?"

"Ne mi? Bugün annem hepsini anlattt... Babamin borcundan tut da..."

"Peki ne olmuş? Nesi var Alinin? Beğenemedin mi?’”s

Muazzez, Ali’yle birlikte olmayacağını dile getirir. Şakir olayında tepki veremeyen kız, ilk defa kararını açıklamış ve bu ilişkiyi reddetmiştir. Para karşılığında satıldığını düşünerek Yusuf’a insani bir tepki göstermiştir.

Hacı Etem ile Şakir, 320 liranın nereden geldiğini öğrenmiştir. Fabrikatörün oğlu Şakir, korkak, miskin bakkalın kendisinden üstün tutulmasından hiç hoşnut değildir. Artık Ali'yi düşmanı olarak görmektedir. ${ }^{29}$ Bu duygunun etkisiyle bir düğün akşamında sarhoş haliyle oynarken, Ali'yi silahıyla öldürecektir. Olay sonrasında Şakir, karakola götürülür. Her zamanki ayakçları Hacı Etem tarafından oracıkta nöbetçi Cemal Çavuş satın alınmıştır. Görgü tanıkları uyarılır. Silah değiştirilir. Şakir içerden çıkarılır. Yargılandığı bu davadan beraat eder. Öyle ki dönem itibariyle kanıksanmış bir gerçekliktir: "Hapishane ancak serseriler, köylüler ve aşağı tabakadan insanlar 


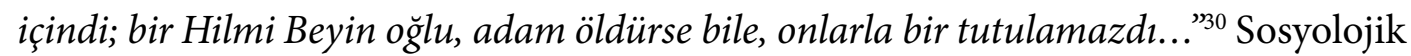
yaklaşımla değerlendirdiğimizde yazar, çok renkli olarak ve büyük bir sevgiyle çizdiği bir Türk düğün tablosunda, Edremit’in "avare gençliğinin” çok çirkin âlem yapma sahnesini alçakça işlenen bir cinayetle aktarırken, mevcut sosyal düzenin eleştirisini yapmaktadır. Bu ve bundan sonra gelen birçok sahne, örneğin, mahkeme sahnesi, yalancı tanıkla katilin beraat etmesi, gündelikçi kadının ırzına geçilen kızını savunan Yusuf'a yapılan suikast, Yusuf köylerdeyken onun evinde yapılan oturak âlemi vb.; bu 20.yüzyılın başlarında Osmanlı Türkiye’sinin bir taşra kasabasına yuva kuran ve egemen olan kötülüğün çok inandırıcı ve en son ayrıntısına dek işlenerek çizilmiş bir sosyal tablosu olarak Kuyucaklı Yusufu, toplumsal bellek oluşturmak adına ölümsüz kılmaktadır. $^{31}$

Hilmi Bey ve oğulları gibi tiplerin hapishane yüzü görmeden karanlık işler çevirmeleri, suç işledikleri halde bir ceza almamaları bozuk bir sosyal düzende, sıklıkla rastlanan adaletsizlik örneklerdir. Ekonomik ve sosyal güç sahibi eşrafın, o tarihlerde işledikleri suçlar nedeniyle nasıl aklandıklarını romandan çıkarabilmekteyiz. Eşraf kesiminin bu yönü, toplumcu Türk romanında işlenen konuların başında gelmiştir. Romandaki bu sosyolojik olgunun irdelenmesinden sonra Ali’nin ölümünün bireysel sonuçlarına bakalım: "Ailenin diğer üç ferdi, hatta bu cinayetten içten içe memnundular. Şahinde bir bakkala kız vermediğine seviniyordu, Yusuf hem bir yükten kurtulmuş gibi kendisini serbest sanıyor, hem de, derinden derine üzülüyordu. Muazzez ise, artık gönlündekini açı̆̆a vurabileceğini düşünerek memnundu."32 Bunun getirisi, Yusuf ile Muazzez arasında sevgiye dayalı bir duygu yani aşkın başlaması olur. Aşk, Sabahattin Ali'nin hayatı ve eserlerinin yorumunda anahtar bir kelimedir. Özellikle roman kahramanlarının hayatiyet kazanmasında ve yaşamasında; olayların yönlendirilmesinde ve aksiyonu sağalayan temel fikri güçlerin harekete geçirilmesinde, aşk unusuru daima ön planda karşımıza çıkar. Kuyucaklı Yusufta; Yusuf-Muazzez aşkı buna bir örnektir. Kuyucaklı Yusufta hedef obje; Muazzez'dir. Muazzez, insanın en soylu, en temiz ve en yüksek duygularını, ebedi saadetini ve mutluluğunu temsil eder. Yani bir bakıma Muazzez'e karşı duyulan ilgi ve isteğin, bu değerlere yönelik bir mesajı da içinde taşıdığı söylenebilir. ${ }^{33}$ Muazzez, Yusuf'a karşı duygularını ifade ederken, ona hep inanır, güvenir. Beklentisi asla "bırakılmamaktır." İlgiye açlı̆̆ı, korunaksızlı̆̆ı, saflığı ve masumiyeti ile Muazzez, kaçıp gittikleri bir yaylı arabanın içinde Yusuf’la birlikte olur. Sonra sığındıkları köyden Salâhattin Bey onları almaya gelir. Yusuf, baba olarak benimsediği bu adamı kıramaz ve eve dönmeyi kabul ederler.

$\mathrm{Bu}$ arada hastalığı ortaya çıkan Salâhattin Bey’in, genel sağlık durumu ağırlaşmaya başlamıştır. Yusuf'un işe girmesi gerekmektedir. Çünkü “hasta babanın ekmeği daha ne kadar yenebilirdi? Şahinde’nin gitgide bir yılan gibi parlamıya başlıyan gözlerinin kamçısı hiç Yusuf'un üzerinden eksilmeyecek miydi?"34 Bunun üzerine Yusuf, üvey babasının teklifiyle kaymakamlıkta tahrirat kâtibi olarak görev almayı kabul edecektir.

30 Ali, Kuyucaklı Yusuf, s.135.

31 Leyla Alkayeva, “Sabahattin Alinin Romanlarında Hümanizm”, s.89-90.

32 Ali, Kuyucaklı Yusuf, s.147.

33 Korkmaz, "Sabahattin Ali -İnsan ve Eser-", s.234-235.

34 Ali, Kuyucaklı Yusuf, s.199. 
Bir süre sonra sağlığı giderek bozulan üvey baba kalp krizi geçirip ölür. Bu ölümden sonra yeni gelen kaymakam, bir oyunla Yusuf'u tahsildar yapıp evden uzaklaşmasını sağlar. Bu kararı almasında kasaba eşrafı belirleyici olmuştur. Böylece Şahinde, ev ortamında eğlence etkinlikleri hazırlamak için eline geçirdiği her fırsatı değerlendirebilecektir. On beş yaşındaki kızı Muazzez, önceleri diretir sonra alkolün etkisiyle gecelere katılır, ama aklı Yusuf'tadır, onun ilgisini düşünür ve kendisini alıp gitmesini bekler. Ara ara Yusuf, Şahinde’yi, Muazzez'in başına geleceklerin sorumlusu göreceğini söyleyerek tehdit eder: “...parmak kadar çocuğu benim yokluğumda kötü yollara saptıranların kökünü kazırım..."35 Muazzez’e ilişkin söylentiler, Yusuf'u artık huzursuz etmektedir.

Şahinde, sadece ölen kocasına karşı kaprisli ve saldırgan değil, aynı zamanda kimseden çekinmeyen ahlâksız bir kadındır. Yaşadıkları yörenin umursamaz zenginlerinin etki alanına girmekten özenle kaçan kocasının tersine, cahilliğinin de etkisiyle, kiminle görüştügüne aldırış etmez. Güç ve zenginliğin çekiciliğine kapılarak, yöredeki bir fabrikanın sahibi olan zengin ve kibirli Hilmi Bey’in ahlâksız ailesiyle dostluk kurar. Bu ailenin ahlâkî düşüklüğü özellikle cinsellik alanında betimlenmiştir: Evin hanımı lezbiyendir, baba ve oğul, ölçüsüz, kuralsız ve sorumsuz bir cinsel hayat yaşar, ergenlik çă̆ındaki çocukları kendi zevkleri için baştan çıkarır, fakir halkın korumasız genç kızlarına tecavüz ederler. ${ }^{36}$ Muazzez’in kasaba ileri gelenleri için bir zevk aleti haline geldiğini anlayan Yusuf'un, onun saflığına inandığına göre, Şahinde’ye tehditler yağdırmak yerine, karısını alıp bu pislik yuvasından uzaklaşması beklenen bir davranışken, bu konuda okur adeta hayal kırıklığına uğrar. ${ }^{37}$ Yusuf'un sosyal düzene entegre olma girişimlerine kesinlikle son verecek olan olaysa; onun beklenmedik bir zamanda eve dönüp kendisini sarhoş karısı ve kayınvalidesi eşliğinde yiyip içen kalabalık bir erkek topluluğunun karşısında bulması ile cereyan eder. Kadın üzerine icra ettiği kontrolün yeni sosyal şartlarda aldığı dolaylı biçim, erkeği eskisine nispetle daha huzursuz ve asabi kılmakta, korkularının gerçeğe dönüşmesi halinde tepkilerini çok şiddetli hale getirmektedir. Nitekim deli gibi ateş etmeye başlayan genç adam, orada bulunanların büyük bir kısmını öldürüp karısını yaralar. ${ }^{38}$ Muazzez’in yarası ölümüne neden olur. Sonrasında Yusuf onu bir yol kenarında kazdığı toprağa gömer... Roman, Yusuf'un içinde yeşeren öfkeli bir gencin duruşuyla sonlanır.

Kuyucaklı Yusuf başlangıçta üç ciltlik olarak tasarlanmıştı. Pertev Naili Boratav ile Cevdet Kudret'in aktardığg bilgilere göre, Kuyucaklı Yusufun bir üçlemenin ilk ciddi olarak yazıldığını ve Yusuf'un bir eşkıya karakterinde işleneceği ikinci cildin Çineli Kübra adını taşıyacağını öğrenmiş bulunuyoruz. ${ }^{39}$ Bir kadın adını taşıyan bu ikinci cilt yazılmış olsaydı, kuşkusuz feminist edebiyat eleştirmenleri için önemli bir çözümleme belgesi olacaktı. Yapıtlar kaleme alınmadığı için Yusuf’un sonraki yaşamı

35 Ali, Kuyucaklı Yusuf, s.261.

36 Ayşe Saraçgil, Bukalemun Erkek, Osmanlı İmparatorluğu’nda ve Türkiye Cumhuriyetinde Ataerkil Yapılar ve Modern Edebiyat, s.322.

37 Sevim Kantarcıoğlu, Yakınçă̆ Tarihimizde Roman, s.332

38 Ayșe Saraçgil, Bukalemun Erkek, Osmanlı İmparatorluğu’nda ve Türkiye Cumhuriyeti’nde Ataerkil Yapılar ve Modern Edebiyat, s.324.

39 Berna Moran, Türk Romanına Eleştirel Bir Bakış2. İstanbul: İletişim Yayınları, 1999, s.34. 
hakkında bilgimiz yok. Ancak bazı çıkarımlar yapılabilir. Karısını toprağa gömdükten sonra Yusuf'un daha kararlı olduğunu görüyoruz. Belki de Yaşar Kemal'in İnce Memed'i gibi bir sosyal eşkıya olarak karşımıza çıkacak ya da Kübra’yı bulacaktır... Romanda toplumsal cinsiyet eşitsizliğini acımasızca yaşayan Kübra ve annesiyle ilgili şu olay akışını da tartı̧̧mak gerekir: Çineli anne, eşi tarafından terk edilmiş, kızı Kübra ile bir başına kalmıştır. Kaşık kıran Hayriye ile kaçan kocasını ararken, kaymakamdan yardım istemeye giden kadına kaymakamın tavrı eleştiriye değerdir. Kocası tarafından terk edilen bir ailenin arayışlarına mülki amirin söyledikleri erkek egemen yapının hoyrat ve aşağılayıcı yüzünden başka bir şey değildir: "Hatun, kocanı biz de arıyoruz. Kaşık kıran dedikleri Hayriye’yi almış, kaçmış. Ama kabahat sende: Kocanı zaptetmesini bilmemişsin... Artık ondan sana hayır gelmez. Başının çaresine bak! dedi. ${ }^{340}$ Kadın, kocasının evden ayrılmasının nedeni gösterilir. Ve yoksulluk içine sürüklenen bu anne ile kızı, erkeklerin dünyasında ötekileştirilirken, başlarına gelen kötü olaylara rağmen kendi yollarını aramaya devam edeceklerdir. Romanın bütünsel değerlendirmesini daha rasyonel yapabilmek adına toplumsal cinsiyet açısından eğitim konusunu da yeri gelmişken ele almakta fayda var. Öyle ki, romanın kaleme alındığı tarihsel dönemin toplumsal koşulları düşünüldüğünde, romanın geçtiği kasabada kız çocuklarının eğitim açısından daha iyi bir durumda olduklarına dair çıkarımlar yapabilmekteyiz. Örneğin Muazzez ilkokulu bitirmiştir. Komşulardan nakış, gergef ve dikiş öğrenmiştir. Hatta terzi Mürüvvet’ten bir süre ud dersi almıştır. Yani kız çocuklarına eğitim kapılarının aralandığını nadiren de olsa görmek mümkündür.

Bu bölümle ilgili özetle Kuyucakl Yusuf, Anadolu gerçeğinin yoksulluk ve geri kalmışlı̆ıını, belli bir gelişme modeline bağlı olarak değil, devlet kurumları tarafından da desteklenen yerel seçkinler ile halk arasında yaşanan bir kültür ve ahlâk çatışması çerçevesinde sergiliyor. Batı Anadolu’nun bir kasabasında, Edremit'te geçen romanda, şehir/köy çatışması, romantik edebiyatın işlediği doğa/toplum düzeni ikileminde ifade ediliyor. Fakat bu kasaba, ahlâksızlık, yolsuzluk ve sömürünün hâkim olduğu, hükümet kurumları tarafından desteklenen güçlü ve zengin bir azınlığın hiçbir cezadan korkmadan halkı baskı altında tuttuğu yerdir. Sosyal kontratın temelindeki yasalar, bu azınlığın kural tanımaz iktidarını meşru kılmaktan başka bir işleve sahip değilmiş gibidir. ${ }^{41}$

\section{Romanın Kadın KahramanlarınıToplumsal Cinsiyet Açısından Değerlendirmek}

Bugün dünyada kadın artık sadece evi yuva yapan, çocuk yetiştiren ya da topluluklarda hoşluğuyla yetinilen biri diye düşünülmüyor; eğitim, çalışma ve idare alanında etkinlik gösteren, hatta uzaya gidenler arasında yeri olan biri diye düşünülüyor. Ama yine de kadın olmanın zorlukları ortadadır. Ataerkil geleneklerin yaygın olduğu toplumlarda kadınlar lehine değişim zor olmakta, hatta çeşitli şekillerde engellen-

40 Ali, Kuyucaklı Yusuf, s.65.

41 Ayşe Saraçgil, Bukalemun Erkek, Osmanlı İmparatorluğu’nda ve Türkiye Cumhuriyetinde Ataerkil Yapılar ve Modern Edebiyat, s.318. 
mektedir. ${ }^{42}$ Kadının ve de erkeğin, toplumdaki yerini, toplumların evrimleşme süreci doğrultusunda çizilen bu çerçeve içinde aramak gerekir. Bir üretim gücü olan kadına üretim sürecinde verilen yeri dikkate almaksızın, kadının üst yapı kurumları karşısındaki durumundan hareket ederek çözümlemelere girişmek, sorunu tek boyuta indirgemek demektir. ${ }^{43}$ En basitinden ataerkil toplumlarda kadınların yeri ve önemi, katı toplumsal cinsiyet rolleriyle çerçevelenmiştir. Toplumsal cinsiyet açısından bakıldığında ne geçmişin feodal toplumları ne de günümüzün azgelişmiş ya da gelişmiş toplumlarında, kadının sosyal statüsüne dair tartışmalar bir sonuca ulaştırılmamıştır. Kuşku götürmez bir şekilde; kadının toplumsal yapıyla ilgili sosyal değişme süreçlerine rağmen istenilen yerde olmadığ ${ }_{1}$ ortadadır.

Sanat dünyasında her toplumsal tarihsel dönemde, ekonomik gelişme göstergeleri ne olursa olsun, edebiyatçılar, özellikle romancılar yaşadıkları toplumun gerçeklerini işlemekten geri durmamışlardır. Hayatın önemli bir unsuru olarak kadın olgusu da bu işlenen gerçeklikler arasında yerini almıştır. Sanat, özelde edebiyat kadını bireyselliği içinde işlediği gibi toplumsal alanda çok çeşitli aşamalarda konu edinir. Bu nedenle sanatta kendisini gösteren, açı̆̆a çıkan, her zaman hayattır, insandır. Sanat hayatta temel olanı kavrar. ${ }^{44}$ Özellikle toplumcu gerçekçi romancılar bu anlamda, ele aldıkları toplumun gerçeklerini yansıtmaya özen göstermişlerdir. Bu romancılar içinde Sabahattin Ali’nin önemli bir yeri vardır. Ali, Türkiye toplumunu ilgilendiren sosyal konuları daha 1900'lü yılların başında romanlarında işlemeye başlarken, erkek ve kadın roman kahramanlarını toplumsal ilişkileriyle bir bütün halinde vererek, erkeğin ve kadının sosyal durumlarını toplumsal gerçekle ilintili bir şekilde roman içeriğine yerleştirmiştir. Kuyucaklı Yusuf, bu yönlerden kayda değer sosyolojik veriler içermektedir. Örneğin romanda kadınlar, şiddetten, tacizden, yoksulluktan olumsuz etkilenen yaşamlarıyla gözümüzün önündedir. Ucuz iş gücü olarak zeytinliklerde çalışırlar, evde hizmetçilik yaparlar. Kadınlar, erkeklerin oluşturduğu ve cinsiyetçi kültür formlarıyla kurulu bir dünyada, girdikleri sosyal ilişkiler içinde ayrımcılığa uğrar ve meta yerine konurlar... Dahası üvey anne kötüdür. Üvey oğul bile, üvey babasından ataerkil bir tutumla, üvey annesinin hesabının görülmesini bekler. Çünkü kadın, babanın iktidarını üzerinde kurması gereken bir bedendir. Öyle ki, "zaten Şahinde kadar mânasız, dırdırcı, ne yaptığını bilmez bir kadına peygamberce bir sabır ile tahammül eden bu adam, Yusuf'u ilk günden beri hayrete düşürüyordu." ${ }^{55}$ Ona göre Şahinde güvenilmez bir kişiliğe sahiptir. Hatta kaymakam hastalandığını fark ettiğinde, karısı "...Şahinde’ye bir türlü güvenemiyor ve kızını onun elinde bırakıp gideceği için biraz da telâş ediyordu." "U6 Üstelik uğruna vukuat çıkarılan kızına, bu küçük yerde iyi gözle bakılmayacağı endişesini taşıyordu. Şahinde kendisini düşünen, rahatlığını önemseyen, aklını kullanamayan, kurnaz özellikleriyle romanda var kılınmıştır. Bu niteliği, okuyucunun gözünde bir nefrete dönüşebilmektedir. Yusuf ile

42 Esin, Örücü, “Hukukta Kadın ve Son Gelişmeler”, Türkiye’de Kadın Olmak, haz., Necla Arat, İstanbul: Say Yayınları, 1994, s.21.

43 Füsun Tayanç. Tunç Tayanç, Dünyada ve Türkiye'de Tarih Boyunca Kadın, Ankara: Toplum Yayınları, 1977, s.16.

44 Takiyettin Mengüşoğlu, İnsan Felsefesi, İstanbul: Doğu Batı Yayınları, 2017, s.323.

45 Ali, Kuyucaklı Yusuf, s.117.

46 Ali, Kuyucaklı Yusuf, s.153. 
Muazzez evlenip, kaymakamın isteğini kırmayarak eve geri döndüklerinde, yazar, Yusuf’a Şahinde'yi anlattırırken ister istemez bu nefreti büyütmüştür: “...yaşlandikça düzgüne merak saran, saçlarım acaip otlarla boyayan, kaşlarına çatma rastık çeken ve ahbaplarıla dostluğu yavaş yavaş dedikodulu bir hal almıya başliyan bu kadın, hattâ hiç eve gelmese daha iyi olacaktl. ${ }^{{ }^{47} 7} \mathrm{Ne}$ var ki üvey annesinin neler yaptığını, neler yapabileceğini tahmin eden Yusuf, giderek yoksullaşan bu hanede, eşini annesinin insafına teslim etmiştir. Yusuf'un kadınlara ilişkin düşüncelerini okuyucuya aktarmaktan geri durmayan yazarın, Muazzez söz konusu olduğunda Yusuf için kullandığ 1 şu cümleler kanımızca Yusuf'la ilgili az çok bilgilendiricidir: "kadın dedikleri şey hakkında hiçbir fikri olmıyan delikanlı..."

Kötü kadın rolü verilen üvey anneye geri dönelim. On beş yaşındaki kızını gezmelere götüren Şahinde için, kendi evlerinde verilen alemlerde kızının erkeklerin kollarında gezinmesi ahlaki bir anlam ifade etmemektedir. Yemekler ve eğlenceler ile kasaba ileri gelenleri ona yetiyordu. Kızını, köylerde tahsildarlık yapan Yusuf'tan uzaklaştırmak için her türlü yolu deniyordu: “...sen böyle kendini evlere kapayıp, aman biz fakir düştük, aman ekmeğimiz kalmad,, aman kocam gelmedi, derken, kocan olacak herif ne yapıyor dersin? Yumurtayı, tavuğu, manda kaymağını yiyip at üstünde safa sürüyor. Karım ne yapıyor, ne ile karnını doyuruyor diye tasa ettiği var mı?"49 Kızını böyle işleye işleye ortamlara çekmeyi başarmıştır. Hatta kızını cahillikle suçlarken, yeri gelir karın doyurmanın marifetinden dem vurarak istediği sonuca ulaşmayı başarır: "...Illk günlerde biraz şaşıran Muazzez, yavaş yavaş kör bir gevşekliğin içine kendini bırakıyordu... ${ }^{.50}$ Muazzez, annesinin yönlendirmesiyle, Yusuf eve geldiğinde ona yalanlar söyler. Öyle bir hale gelir ki: “...bir kere, madem ki annesi onunla beraberdi ve o her şeyi muvafik görüyor, hattâ tertip ediyordu, artık kendisine söz düşmezdi. Sonra ortada kimseye kötülïk yapıldığı da yoktu. Birkaç ahbaba gidip gelmek, onların erkekleriyle oturup kalkmak, büyük bir cinayet değildi. ${ }^{\prime 51}$ Annesi tarafından öyle ileri götürülüyordu ki, "Muazzez bazı günler deli gibi çırpınıyor, "Yusuf, Yusuf!" diye bağırıyordu. Onun her şeyi haber almasını, eve gelip kendisini dövmesini, hattâ bıçaklamasını, ortalığın altını üstüne getirmesini istiyor, ancak o zaman bu işlerden sıyrılabileceğini seziyordu." ${ }^{2}$ Bunun yanında "şimdi akşamın olmasını, sofranın kurulmasını, yahut bir yere gitmelerini biraz istiyerek bekliyor, rakı kadehlerini daha az yüz buruşturarak içiyor ve koluna gümü̈s bir bilezik takan bir erkeğin kucağına oturmaktan eskisi kadar nefret etmiyordu." ${ }^{\prime 53}$ Kuşkusuz yaşam koşulları, insanların içine düştükleri açmazları belirliyordu. Şahinde'ye kalsa sürüklendikleri dramın sorumluluğu ölen eşi ve üvey oğluna aitti: “...Eğer fena bir şey yapıyorlarsa bunun mesuliyeti daha ziyade Yusuf'a, hattâ merhum kocasına aitti. Hiç olmazsa mesuliyetin büyük bir kısm!! Onlar bu evin istikbalini düşünmüş, akıllıca hareket etmiş olsalardı, şimdi Şahinde ile kızı elin herif-

47 Ali, Kuyucaklı Yusuf, s.193. 48 Ali, Kuyucaklı Yusuf, s.196. 49 Ali, Kuyucaklı Yusuf, s.246. 50 Ali, Kuyucaklı Yusuf, s.247. 51 Ali, Kuyucakl Yusuf, s.248. 52 Ali, Kuyucaklı Yusuf, s.252. 53 Ali, Kuyucaklı Yusuf, s.253. 
lerine, dalkavukluk edip onları eğlendirmeye mecbur kalmazlardı..."54

Sabahattin Ali’nin roman dili cinsiyetçi olmamakla birlikte, romanını dayandırdığı sosyal yapı cinsiyetçi bir temele sahiptir. Örneğin romanda kadınlar için tipik bazı davranışlar göze çarpar: Mahalle kadınları dedikoducu ve gözetleyicidir. Kadınların toplumsal cinsiyet rolleri belirgindir, Muazzez de yemek pişirir, çamaşır yıkar. Ev hizmetlerinde kadınlar çalıştııılır. Erkeklerin âleminde kadınlar oyun ve zevk aracı olarak kullanılır. Ne yazık ki kadınlar kendilerinden kötülük beklenen varlıklar olarak karakterize edilirler. Yani cahil, kurnaz, korunmasız, iğneleyici, ilgiye muhtaç, kendine hâkim olamayan, dedikoducu, arkadan dolap çeviren ve bencil... Birçok çalışmada da ileri sürüldüğü gibi eril hegemonyanın müdahaleden çekinmediği kadınların tarihi, üreme, çocuk yetiştirme, cinsellik, duygusallık, ev içi mekânlar ve ekonomiler, küçük el sanatları gibi kadınların tarihteki temel ve asli yapıp etmeleri olarak görülmüştür. ${ }^{55}$ Sonuçta Kuyucaklı Yusufta, yazıldığ 1 toplumun gerçeklerini aktaran yazar, toplumsal cinsiyet hiyerarşisinin duvarlarıyla hapsettiği kadınların psikososyal gerçekliğini görmek adına birçok sosyal veriyi sunmaktadır. Kuşkusuz yazarın, romanı kurgularken amacını belirleyen ve romanının temelindeki oluşturucu ilke olan, dünya görüşünü gerçekleştirme çabasını da burada anmak gerekir. ${ }^{56}$ Erkek egemen toplum Muazzez'in ölümüne neden olmuştur. Bu cinayeti o toplumun erkekleri el birliğiyle gerçekleştirmişlerdir. Olaydan sonra Yusuf, kazdığı toprağa Muazzez’i gömer. Atına binerek yüzünü kasabaya dönmesi ya gecikmiş bir özeleştiridir ya da gelecek için bir başlangıç: “... bir kere daha dönüp geriye baktıktan ve ömrünün en korkunç senelerinin geçtiği bu kasabaya yumruğunu uzatıp tehdit eder gibi salladıktan sonra, atın ileriye, dağlara doğru sürdü. İçindeki bütün yıkıntılara, bütün kederlere rağmen başın yere eğmek istemiyordu. Matemini ortaya vurmadan tek başına yüklenecek ve yeni bir hayata doğru yürüyecekti. ${ }^{57}$ Toplum bu olanağı ona verecektir. Muazzez içinse toprağa sessiz bir beden bırakmıştır...

Sonra doğru giderken, Kuyucaklı Yusuf romanıyla ilgili unutulmaması gereken şu realiteyi bir kez daha anımsatmakta fayda görmekteyiz: Romanda yan karakterler halinde verilen bir anne kız üzerinden yazar, ataerkil toplumda erkek egemen kurumsallaşmanın daha kötü bir yönünü okuyucuya göstermiştir. Başlarından geçen olaylardan sonra hizmetçi olarak kabul edildikleri kaymakamın giderek yoksullaşan evinde Çine'li Kübra ve annesi, yaşamlarıyla ilgili bir düzelme olmayacağına inanarak, evden ayrılıp bir bilinmeze doğru yol alırlar. Anne, kızının başına gelenlerden dolayı faillerin ceza almayacağını kanıksamıştır. Adaletin gerçekleşmeyeceğini düşünen anne rahatlıkla şu nitelendirmede bulunur: "...parası olanın ırzı da tamam, namusu da!"58 Romanda az yer verilen bu iki kadın, Şahinde ve Muazzez'in cinsiyetçi tahakküme yenilmelerinin yanında, dikkate alınması gereken roman kahramanlardır. Kısaca Muazzez ve Kübra’yı odağa alarak bakacak olursak da bu iki kadınlık

54 Ali, Kuyucaklı Yusuf, s.254.

55 Zainab Bahrani, Babil’in Kadınları, Mezopotamya'da Toplumsal Cinsiyet ve Temsil, çev., Sercan Çalcı, İstanbul: Kolektif Kitap Yayınları, 2018, s.27.

56 Georg Lukacs, Çağdaş Gerçekçiliğin Anlamı, çev., Cevat Çapan, İstanbul: Payel Yayınları, 1986, s.23.

57 Ali, Kuyucaklı Yusuf, s.283.

58 Ali, Kuyucaklı Yusuf, s.163. 
modelleri üzerinden kırsaldaki patriyarkaya ve sosyal düzeni kapsayan gerçekleri, erkek egemen yönetim anlayışından ayrı tutmamak gerekir. Kamusal alanda kadınların karşı karşıya kaldıkları haksızlıkların temelinde, sosyal düzenin baskın bir şekilde erkek kontrolünde olması yatar. Böylece kadınlar psikososyal yaşamlarıyla, toplumsal cinsiyet ilişkilerinin çerçevesinde, çözümlenemeyen bir özgürleşme sorunuyla karşılaşırlar. Bu, kırsal dünyanın sosyal-ekonomik şartlarında daha ağır seyretmektedir.

Kısaca diyebiliriz ki, Sabahattin Ali Kuyucaklı Yusufta, bir Anadolu kasabasını, bütün insani ve sosyal gerçekliğiyle veriyor: Soylu insanlarıyla, bayağı insanlarıyla; sevinçlerle, üzüntülerle; sevgilerle, nefretlerle; yoksullukla, zenginlikle; umutla, umutsuzlukla... Yarattığı insanlar, o çağın, o çevrenin insanları; birbirleriyle ilişkileri, belirli şartların biçim verdiği ilişkiler. ${ }^{59} \mathrm{Ne}$ var ki bunlar çoğunlukla, kadının özgür bir irade olarak yer almadığ 1 ilişkilerdir.

\section{Sonuç}

Geleneksel ataerkil toplumlarda, sosyalleşme sürecinden geçen her birey gibi kadın da bu toplumdaki baskın olan erkek egemen sosyal ilişkilerin belirlediği toplumsal koşullar tarafından çevrelenir. Cinsiyet hiyerarşisinin keskin sınırlarla korunduğu bu toplumlarda kadınlar, erkeğin lehine işleyen kamusal ve mahrem alanlarda kolaylıkla toplumsal cinsiyet ayrımcilı̆gına uğrarlar. Korunmasız ve güçsüzdürler. Yeri gelir elde edilmesi gereken, sahip olunduğunda biat ettirilen ve buna çeşitli toplumsal dinamiklerce hazırlanan bedensel bir gösterge olarak görülürler. Doğal olarak kadınlar da ataerkil toplumlarda, yetiştikleri toplumun çelişkilerini tutumlarında, kuşkuya yer bırakmayacak şekilde taşırlar. Bunun edebiyat yapıtlarında, özellikle romanda yansımasını bulduğuna dair analizlere literatürde rastlamaktayız. Roman bu yönüyle, toplumda kadının odakta olduğu sorunlarının tespiti ve tartışılması için eleştirel bir okuma alanı açmaktadır. Ayrıca romanın bir edebi tür olarak hem yazıldığı dönemin sosyal şartlarını yansıtmasından hem de bu dönemin egemen unsurlarına yönelik toplumsal değiştirme gücü olarak fonksiyon icra etme özelliğini, Kuyucakh Yusuf un başardığını söyleyebiliriz. ${ }^{60}$ Kuyucaklı Yusuf, erkek egemen sosyal etkileşim unsurlarının if̧̧a edilmesi anlamında da gerçekçi bir olay örgüsüne sahiptir. Kantarcıŏ̆lu’na göre bu roman, tek partili cumhuriyet döneminin sosyal-ekonomik ortamına ve hatta bugüne kadar uzanan zaman içinde Türk toplumunda yaşananlara getirilen bir yorum ve bir eleştiri olma niteliğinden hiçbir şey kaybetmemiştir. ${ }^{61}$ Türk romanlarına Marksist açıdan bakan Tatarlı ve Mollof'a göre ise: Sabahattin Ali, romanında, o dönem mevcut olan burjuva çiftlik sahibi sınıflarının, burjuva toplumunun yozlaşmışlığını, ahlaki düşkünlüğünü ve sosyal adaletsizliğini canlandırmıştır. ${ }^{62}$ Romanı, bu niteliklerinden yola çıarak, şöyle bir sosyolojik bağlama oturtmak mümkündür: Tanzimat'tan 1950'lere kadarki Türk romanının sorunsalını büyük ölçüde Batılılaş-

59 Fethi Naci, 100 Soruda Türkiye’de Roman ve Toplumsal Değişme, 1990, s.316.

60 Mustafa Kemal Şan, “Türk Modernleşmesine Romandan Bakmanın Önemi Üzerine”, Edebiyat Sosyolojisi Incelemeleri, ed., Köksal Alver, Ankara: Hece Yayınları, 2012, s.248.

61 Kantarcioğlu, Yakınçă̆ Tarihimizde Roman, 1908-1960, s.320.

62 İbrahim Tatarlı, Rıza Mollof, Marksist Açıdan Türk Romanı, İstanbul: Habora Kitabevi Yayınları, 1969, s.72. 
ma hareketi belirlemiştir. ${ }^{63}$ Sabahattin Ali’nin Batılılaşmaya eğilmeden, Kuyucaklı Yusufu söz konusu tarihten çok önceleri yazmış olması, konuyla ilgili özgünlüğünü göstermektedir. Çünkü yazarlarımız toplumsal yapının kendine yönelmiyor, mevcut düzeni sorgulamıyorlardı. Toplumsal yapıyı, ezilen halk ya da köylü sınıfının durumunu ele alan romanlar 1950'lerden sonra görülür, bunların ilk örneği 1937'de yayımlanan Kuyucaklı Yusuftur. Romana Anadolu'yu da bu sorunsalla birlikte getirmiş olması Kuyucaklı Yusufu başka bir yönden daha öncü yapar. Sabahattin Ali, bürokrasi, eşraf ve ezilen halkı ele alırken, kapitalist üretim biçiminin bütün unsurlarıyla yerleşmediği, yarı-feodal bir toplumsal yapıdan kaynaklı çatışmaları işlemiştir. ${ }^{64}$

Son tahlilde sanatın kendisinin bir toplum gerçeği olduğu ve insanın varlığıyla, insanın durumuyla ilgili toplumsal gerçeği yansıttığı varsayılacak olursa, ${ }^{65}$ Kuyucaklı Yusufun dönemin toplumsal gerçekliğini masaya yatırdığı gibi Türk romanını özgürleştiren bir bilincin de en erken izdüşümlerini içeriğinde taşıdığını söyleyebiliriz.

\section{Kaynakça}

Ali, Sabahattin. Kuyucaklı Yusuf. Haz., Atilla Özkırımlı. İstanbul: Cem Yayınevi. 1991.

Alkayeva, Leyla. "Sabahattin Alinin Romanlarında Hümanizm”. Sovyet Türkologlarının Türk Edebiyatı Incelemeleri. Çev., Tatyana Moran. Yurdanur Salman. İstanbul: Cem Yayınevi. 1980. ss.89-90.

Aytaç, Gürsel. Çăgdaş Türk Romanı Üzerine İncelemeler. 3. Baskı. Ankara: Doğu Batı Yayınları. 2012.

Bahrani, Zainab. Babilin Kadınları, Mezopotamya'da Toplumsal Cinsiyet ve Temsil. Çev., Sercan Çalcı. İstanbul: Kolektif Kitap Yayınları. 2018.

Gülendam, Ramazan. Türkiye’de Kadın Olmak, Cumhuriyet Devri Türk Romanında Kadın Kimliği. İstanbul: Kesit Yayınları. 2015.

Fischer, Ernst. Sanatın Gerekliliği. Çev., Cevat Çapan. 7. Baskı. Ankara: V Yayınları. 1993.

Kantarcıoğlu, Sevim. Yakınçă̆ Tarihimizde Roman 1908-1960. İstanbul: Paradigma Yayınları. 2008.

Korkmaz, Ramazan. “Sabahattin Ali -İnsan ve Eser-”. Doktora Tezi. Firat Üniversitesi Sosyal Bilimler Enstitüsü. 1991.

Kundera, Milan. Roman Sanatı. Çev., Aysel Bora. 5. Baskı. İstanbul: Can Sanat Yayınları. 2014.

Lukacs, Georg. Çă̆daş Gerçekçiliğin Anlamı. Çev., Cevat Çapan. 4. Baskı. İstanbul: Payel Yayınları. 1986.

Mengüşoğlu, Takiyettin. İnsan Felsefesi. 2.Baskı. İstanbul: Doğu Batı Yayınları. 2017. Moran, Berna. Türk Romanına Eleştirel Bir Bakış 1. 3. Baskı. İstanbul: İletişim Yayınları. 1990.

63 Berna Moran, Türk Romanına Eleştirel Bir Bakış 1, İstanbul: İletişim Yayınları, 1990, s.19.

64 Berna Moran, Türk Romanına Eleştirel Bir Bakış 2, s.17.

65 Ernst Fischer, Sanatın Gerekliliği, çev., Cevat Çapan, Ankara: V Yayınları, 1993, s.44-94. 
Moran, Berna. Türk Romanına Eleştirel Bir Bakış 2. 6. Baskı. İstanbul: İletişim Yayınları. 1999.

Naci, Fethi. 100 Soruda Türkiye’de Roman ve Toplumsal Değişme. 2. Baskı. İstanbul: Gerçek Yayınevi. 1990.

Örücü, Esin. "Hukukta Kadın ve Son Gelişmeler”. Türkiye’de Kadın Olmak. Haz., Necla Arat. İstanbul: Say Yayınları. 1994.

Sancar, Serpil. Türk Modernleşmesinin Cinsiyeti, Erkekler Devlet, Kadınlar Aile Kurar. 3. Baskı. İstanbul: İletişim Yayınları. 2014.

Saraçgil, Ayşe. Bukalemun Erkek, Osmanlı İmparatorluğu’nda ve Türkiye Cumhuriyetinde Ataerkil Yapılar ve Modern Edebiyat. Çev., Sevim Aktaş ve Öykü Özgün. İstanbul: İletişim Yayınları. 2005.

Sarıkoca, Erem. Tarihi Güncellemek- Edebiyat Sosyolojisi Açısından Roman. Erzurum: Fenomen Yayıncilık. 2016.

Şan, Kemal Mustafa. "Türk Modernleşmesine Romandan Bakmanın Önemi Üzerine”. Edebiyat Sosyolojisi Incelemeleri. Ed., Köksal Alver. 2. Baskı. Ankara: Hece Yayınları. 2012.

Tarakçı, Gülsüm. “İki Roman Örneğinde Milli Roman”. Türk Romanı Özel Sayısı Hece Aylik Edebiyat Dergisi. 6 /65-66-67. (2002): 481-492.

Tatarlı, İbrahim, Mollof, Rıza. Marksist Açıdan Türk Romanı. İstanbul: Habora Kitabevi Yayınları. 1969.

Tayanç, Füsun ve Tunç Tayanç. Dünyada ve Türkiye’de Tarih Boyunca Kadın. Ankara: Toplum Yayınları. 1977.

Timur, Taner. Osmanl-Türk Romanında Tarih, Toplum ve Kültür. İstanbul: İmge Kitabevi. 2002.

Türkeş, Ömer. “Toplum ve Kimlik Kurma Kılavuzu Olarak Roman”. Modern Türkiye'de Siyasi Düşünce, Dönemler ve Zihniyetler. Ed., Tanıl Bora ve Murat Gültekingil. İstanbul: İletişim Yayınları. 2009. ss.844-868. 


\title{
An Evaluation of Female Heroes in Kuyucaklı Yusuf with Psycho-Social Aspects in the Context of Gender Roles
}

\author{
AZIZZ ŞEKER
}

Abstract: Sabahattin Ali's Kuyucakl Yusuf is a novel that successfully reflected many aspects of the social structure of the social-historical period in which it was written. Set in a district where people from different cultures lived together in the early 1900s, this novel with social content is about Yusuf the orphan, whose parents were murdered by bandits, in a family who adopted him and his relations with both himself and the community in which he lived. Moreover, the write treats the social and socio-cultural aspects of people from different social strata in the social reality where the novel is set. In the novel, we see closely the social status of women in a patriarchal society in which the men who build the gender hierarchy are the dominant gender.In this study, we will discuss a social system where gender is against women in the context of the events in the novel and examine the lives of female heroes (Muazzez, Şahinde, Çineli Kübra) from a psychosocial perspective. Analysis of novel female heroes based on the gender phenomenon reflecting social reality is thought to contribute to a critical evaluation of the visibility of sexist language in the novel.

Keywords: Novel, Gender, Women, Gender discrimination. 